\title{
Analysis of Treatment Outcomes in Patients with Cold Injuries
}

\author{
Alexander F. Potapov, $\mathrm{PhD}, \mathrm{ScD}^{1}$; Albina A. Ivanova, $\mathrm{PhD}, \mathrm{ScD}^{1^{*}}$; Svetlana V. Semenova ${ }^{2}$; \\ Semen D. Nusugurov ${ }^{1}$ \\ ${ }^{1}$ M. K. Ammosov North-Eastern Federal University \\ ${ }^{2}$ Republican Hospital \#2 - Center for Emergency Medical Aid \\ Yakutsk, the Republic of Sakha (Yakutia), Russia
}

\begin{abstract}
Background: The aim of this research was to study the prevalence rate, structure, treatment methods and outcomes for patients with severe frostbite and hypothermia admitted to the Intensive Care Unit (ICU) for patients with thermal injuries.

Methods and Results: We performed a retrospective analysis of the treatment outcomes for 108 patients $(83 / 76.9 \%$ men and $25 / 23.1 \%$ women) exposed to excessive natural cold and treated in ICU-1 of Republican Hospital \#2 - Center for Emergency Medical Aid in the city of Yakutsk in the period 2017-2019. The age of the adult patients ranged from 18 to 77 years (mean age of $47.5 \pm 14.9$ years), and three children were 2,4 , and 17 years of age. The diagnosis of hypothermia was made by measuring the core (rectal) temperature $\left(\mathrm{t}_{\text {rect }}\right)$. The following gradation scale was applied: mild $\left(\mathrm{t}_{\mathrm{rec}} 32^{\circ} \mathrm{C}-35^{\circ} \mathrm{C}\right)$, moderate $\left(\mathrm{t}_{\text {rec }} 28^{\circ} \mathrm{C}-32^{\circ} \mathrm{C}\right)$, and severe $\left(\mathrm{t}_{\text {rect }}<28^{\circ} \mathrm{C}\right)$ hypothermia.

The comprehensive treatment of frostbite was carried out in accordance with modern clinical guidelines. Among all patients with cold injuries, 38(35.2\%) patients with combined hypothermia constituted the most severe category: mild hypothermia was observed in $26(68.4 \%)$, moderate in $7(18.4 \%)$, and severe in $5(13.2 \%)$ patients. Due to the development of tissue necrosis and its non-viability, various surgeries were performed on 33(30.5\%) patients with third- and fourth-degree frostbite, including amputations of various limb segments in $29(87.9 \%)$ patients. The treatment duration for all the ICU patients with cold injury was $4.2 \pm 2.1 \mathrm{bed} /$ days, and for the patients with combined hypothermia $-7.9 \pm 4.4 \mathrm{bed} /$ days. Over the study period, $3(2.7 \%)$ patients with cold injury died.

Conclusion: The presented data show the relevance of the cold injury issue in the region, with severe frostbite with tissue necrosis resulting in amputation of extremities at different levels in $30.5 \%$ of the patients. Moreover, in $35.2 \%$ of the cases, frostbite was combined with hypothermia, which made the treatment even more difficult. (International Journal of Biomedicine. 2020;10(3):274-277.)
\end{abstract}

Key Words: excessive natural cold $\bullet$ hypothermia $\bullet$ frostbite $\bullet$ Far North

\section{Introduction}

Injuries caused by exposure of the human body to extreme cold make up one of the serious problems for emergency medicine. This problem is particularly relevant in the regions situated in northern latitudes and characterized by low and ultra-low temperatures. The Republic of Sakha (Yakutia) (RS(Y) is one such region. $\mathrm{RS}(\mathrm{Y})$ is located in Northeast Siberia and stands out in the Northern Hemisphere for having the longest period of subzero temperatures, which lasts for 6.5-9 months a year.

*Corresponding author: Prof. Albina A. Ivanova, PhD, ScD. M.K. Ammosov North-Eastern Federal University, Yakutsk, the Republic of Sakha (Yakutia), Russia.E-mail: iaa_60@mail.ru
Besides the severe clinical course and frequent complications in the respiratory and excretory systems, cold injury also often results in disability of patients due to amputations of various limb segments. Treatment outcomes depend on the depth of local tissue damage and the level of hypothermia, as well as treatment tactics, especially the adequacy of activities during the pre-thaw phase (from the onset of injury to the beginning of tissue rewarming and restoration of blood circulation) and the early post-thaw phase (from the beginning of tissue warming and restoration of blood circulation to the end of Day 1).

At present, the basic approach to treating patients with frostbite of extremities is to ensure slow and gradual rewarming of the damaged tissues through internal heat production, which helps to prevent tissue necrosis or reduce its area. ${ }^{(1,2)}$ The 
intensive care for hypothermia should first focus on ensuring adequate oxygenation of the body, maintaining hemodynamics and preventing fatal cardiac arrhythmias, which could be caused by general warming of the patient. ${ }^{(2)}$ Today, in the event of death from hypothermia, a number of countries follow the "no one is dead until warm and dead" principle, which was recommended by the European Resuscitation Council in 2015. (3) To this end, modern high-tech treatment methods are applied, including extracorporeal core warming and irrigation of body cavities with warm fluids. ${ }^{(4)}$

Obviously, there are differences in the level of hypothermia, severity of frostbite and, consequently, treatment outcomes between the patients exposed to mild low temperatures $\left(0^{\circ} \mathrm{C}-5^{\circ} \mathrm{C}\right)$ and excessive cold $\left(-35^{\circ} \mathrm{C}-45^{\circ} \mathrm{C}\right)$, when ice formation within the tissue can be observed. In this regard, it is interesting to study the prevalence, treatment techniques and outcomes for patients with severe cold injury at the specialized ward in the region with extremely low temperatures.

The aim of this research was to study the prevalence rate, structure, treatment methods and outcomes for patients with severe frostbite and hypothermia admitted to the Intensive Care Unit (ICU) for patients with thermal injuries.

\section{Materials and Methods}

We performed a retrospective analysis of the treatment outcomes for 108 patients (83/76.9\% men and 25/23.1\% women) exposed to excessive natural cold (ICD-10 codes T33-T35 for Frostbite and T68 code for Accidental Hypothermia) and treated in ICU-1 of Republican Hospital \#2 - Center for Emergency Medical Aid (RH2-CEMA) in the city of Yakutsk in the period 2017-2019. Medical records, intensive follow-up and intensive care histories of the inpatients were studied. The age of the adult patients ranged from 18 to 77 years (mean age of $47.5 \pm 4.9$ years), and three children were 2,4 , and 17 years of age.

The diagnosis of hypothermia was made by measuring the core (rectal) temperature $\left(\mathrm{t}_{\text {rect }}\right)$. The following gradation scale was applied: mild $\left(\mathrm{t}_{\mathrm{rec}} 32^{\circ} \mathrm{C}-35^{\circ} \mathrm{C}\right)$, moderate $\left(\mathrm{t}_{\mathrm{rec}}\right.$ $\left.28^{\circ} \mathrm{C}-32^{\circ} \mathrm{C}\right)$, and severe $\left(\mathrm{t}_{\text {rect }}<28^{\circ} \mathrm{C}\right)$ hypothermia. ${ }^{(2)}$
Statistical analysis was performed using the statistical software «Statistica» (v. 13.0, StatSoft, USA).

\section{Results and Discussion}

An analysis of the data showed that in 2017-2019, ICU-1 of RH2-CEMA treated 108 patients with cold injuries, making up $14.7 \%$ of all the patients admitted to the Unit during the study period (Table 1). For reference, ICU-1 is a specialized ward of the hospital for patients with thermal injuries; thus, it also treats patients with burn injuries, including children. In addition, the unit treats patients after semi-elective reconstructive surgeries to address consequences of thermal injuries (autografting of granulating wounds, cicatricial contractures and tissue deformities).

Of the study group, 38(35.1\%) patients were taken to hospital by Yakutsk Ambulance Service teams, 26(24.0\%) by the Republic Center for Disaster Medicine from district hospitals, $8(7.4 \%)$ were transferred from other medical institutions in the city of Yakutsk, and 36(33.5\%) patients came on their own.

Among all patients with cold injuries, 38(35.2\%) patients with combined hypothermia constituted the most severe category (Table 1). These patients were admitted to the unit in serious or extremely serious condition with $\mathrm{t}_{\text {rect }}$ ranging from $24.5^{\circ} \mathrm{C}$ to $35^{\circ} \mathrm{C}$ (mean $t_{\text {rect }}$ of $32.5 \pm 3.0^{\circ} \mathrm{C}$ ). Mild hypothermia was observed in $26(68.4 \%)$, moderate in $7(18.4 \%)$, and severe in $5(13.2 \%)$ patients.

To ensure adequate oxygenation, all the patients underwent respiratory therapy, which included moist oxygen inhalation and, in one case, artificial ventilation (for severe hypothermia $\left(\mathrm{t}_{\text {rect }} 24.5^{\circ} \mathrm{C}\right)$, unconscious). Target $\mathrm{SpO}_{2}$ values were maintained at a level above $94 \%$.

Infusion therapy of the patients with hypothermia was aimed at maintaining hemodynamics, correcting hypovolemia, improving blood rheology and microcirculation, as well as at preventing acute kidney injury. Crystalloid solutions heated to $40-42^{\circ} \mathrm{C}$ were infused $(15-20 \mathrm{ml} / \mathrm{kg})$ in the first 2 hours and subsequent continuous infusion of $5 \mathrm{ml} / \mathrm{kg} / \mathrm{hr}$. Inotropic support (intravenous infusion of dopamine $3-8 \mu \mathrm{g} / \mathrm{kg} / \mathrm{min}$ ) was required for $6(24 \%)$ patients: all 3 patients with severe

Table 1.

The treatment indicators of ICU patients with cold injury

\begin{tabular}{|c|c|c|c|c|c|c|c|c|}
\hline \multirow[b]{2}{*}{ Years } & \multirow{2}{*}{$\begin{array}{l}\text { Total } \\
\text { number } \\
\text { of ICU } \\
\text { patients }\end{array}$} & \multicolumn{2}{|c|}{$\begin{array}{l}\text { Number of patients } \\
\text { admitted with cold injury }\end{array}$} & \multirow{2}{*}{$\begin{array}{l}\text { Mean temperature } \\
\text { of patients with } \\
\text { hypothermia } \\
\text { at admission to ICU, } \\
{ }^{\circ} \mathrm{C}(\mathrm{M} \pm \mathrm{SD})\end{array}$} & \multicolumn{2}{|c|}{$\begin{array}{l}\text { Treatment duration, bed/days } \\
(\mathrm{M} \pm \mathrm{SD})\end{array}$} & \multicolumn{2}{|c|}{$\begin{array}{l}\text { Number of deaths } \\
\text { (lethality, \%) }\end{array}$} \\
\hline & & $\begin{array}{c}\text { total } \\
(\% \text { of all ICU } \\
\text { patients })\end{array}$ & $\begin{array}{c}\text { including with } \\
\text { hypothermia } \\
\text { (\% of all ICU } \\
\text { patients) }\end{array}$ & & total & $\begin{array}{c}\text { including with } \\
\text { hypothermia }\end{array}$ & total & $\begin{array}{l}\text { including with } \\
\text { hypothermia }\end{array}$ \\
\hline 2017 & 249 & $\begin{array}{c}42 \\
(16.9 \%) \\
\end{array}$ & $\begin{array}{c}14 \\
(33.3 \%) \\
\end{array}$ & $31.5 \pm 3.4$ & $5.2 \pm 3.2$ & $13.5 \pm 4.5$ & $1(2.3 \%)$ & - \\
\hline 2018 & 263 & $\begin{array}{c}29 \\
(11.0 \%)\end{array}$ & $\begin{array}{c}11 \\
(37.9 \%)\end{array}$ & $33.6 \pm 1.6$ & $3.5 \pm 2.0$ & $5.6 \pm 3.4$ & $1(3.4 \%)$ & - \\
\hline 2019 & 219 & $\begin{array}{c}37 \\
(16.9 \%) \\
\end{array}$ & $\begin{array}{c}13 \\
(48.6 \%) \\
\end{array}$ & $33.6 \pm 4.4$ & $3.9 \pm 1.5$ & $4.7 \pm 5.4$ & $1(2.7 \%)$ & $1(2.7 \%)$ \\
\hline Total & 731 & $\begin{array}{c}108 \\
(14.8 \%)\end{array}$ & $\begin{array}{c}38 \\
(35.2 \%)\end{array}$ & $32.9 \pm 3.1$ & $4,2 \pm 2,1$ & $7.9 \pm 4.4$ & $3(2.7 \%)$ & $1(0.9 \%)$ \\
\hline
\end{tabular}


hypothermia and 3 patients with moderate hypothermia. Vascular access was provided by placing a peripheral infusion catheter into an accessible vein; central venous catheters were placed in $9(23.7 \%)$ of the patients with hypothermia. The target values of infusion therapy were as follows: systolic blood pressure $>90 \mathrm{mmHg}$, heart rate in the range of 60 $100 \mathrm{bpm}$, diuresis of $30-60 \mathrm{ml} / \mathrm{hr}$. The rewarming took $1-4$ hours, depending on the level of hypothermia.

The remaining 70(64.8\%) patients were admitted to the hospital without signs of hypothermia but with frostbite in various areas of the body, of which 3(4.3\%) patients were in the pre-thaw phase of the injury and $67(95.7 \%)$ patients were in the post-thaw phase. Thirty-three $(86.8 \%)$ patients with hypothermia had frostbite of the upper and lower extremities of varying severity and, in some cases, with ice formed within tissues.

All of the patients with cold injuries were distributed according to the severity of tissue frostbite, as follows: firstdegree frostbite was present in $10(6.2 \%)$ patients, seconddegree frostbite in 52(32.8\%), third-degree frostbite in $41(37.9 \%)$, and fourth-degree frostbite in $21(19.6 \%)$ patients. One $(0.9 \%)$ patient was admitted with a combined injuryfrostbite of feet and a burn injury; he had a second- and thirddegree flame burn over $25 \%$ of the body surface. The patients often had frostbite in several areas of the body. Frostbite of hands and feet prevailed, amounting to 38.0 and $44.2 \%$ of all frostbites, respectively (Table 2).

Table 2.

Frostbite areas

\begin{tabular}{|l|c|c|}
\hline \multirow{2}{*}{ Frostbite areas } & \multicolumn{2}{|c|}{ Number of patients $(\mathrm{n}=108)$} \\
\cline { 2 - 3 } & $\mathrm{n}$ & $\%$ \\
\hline Upper extremities, including: & 47 & 41.6 \\
hands & 43 & 38.0 \\
forearm & 2 & 1.8 \\
elbow joint area & 1 & 0.9 \\
shoulder & 1 & 0.9 \\
\hline Lower extremities, including: & 63 & 55.7 \\
feet & 50 & 44.2 \\
shin & 3 & 2.7 \\
knee joint area & 4 & 3.5 \\
thigh & 3 & 2.7 \\
clunes & 3 & 2.7 \\
\hline Other areas, including: & 3 & 2.7 \\
face & 2 & 1.8 \\
abdomen & 1 & 0.9 \\
\hline
\end{tabular}

The comprehensive treatment of frostbite on Day 1 after admission was carried out in accordance with clinical guidelines $^{(1)}$ and included infusion of crystalloid solutions, antispasmodic, antiplatelet and antihypoxic therapy, a nerve conduction block in upper and lower extremities and pain management in case of pain syndrome. Heat-insulating cottongauze compresses were applied to affected areas, regardless of the assumed degree of damage, to ensure their slow and gradual rewarming. In addition, according to the order of the MHRF No. 174 dated 05.17 .1999 , tetanus prophylaxis is mandatory for this category of patients. ${ }^{(5)}$ On the following day, bandages medicated with antiseptic solutions or antibacterial water- soluble ointments were applied to the affected areas.

Due to the development of tissue necrosis and its nonviability, various surgeries were performed on 33(30.5\%) patients with third- and fourth-degree frostbite (Table 3).

Table 3.

Number and types of surgeries performed on patients with cold injuries in 2017-2019

\begin{tabular}{|l|l|c|c|c|c|}
\hline \multicolumn{1}{|c|}{ Types of surgeries } & 2017 & 2018 & 2019 & total \\
\hline \multirow{4}{*}{1} & Extremity amputation, including: & 5 & 8 & 16 & 29 \\
\cline { 2 - 7 } & - amputation of toes and fingers & 3 & - & 1 & 4 \\
\cline { 2 - 7 } & - mid-leg amputation of both legs & 1 & - & 3 & 4 \\
\cline { 2 - 7 } & - foot (feet) amputation & - & 1 & 1 & 2 \\
\cline { 2 - 6 } & - toes amputation & - & 1 & - & 1 \\
\cline { 2 - 7 } & - hand amputation & - & 1 & 1 & 2 \\
\cline { 2 - 7 } & - amputation of one or more fingers & - & 1 & 4 & 5 \\
\cline { 2 - 7 } & - finger amputation on both hands & 1 & 4 & 6 & 11 \\
\hline 2 & Necrectomy & - & 1 & - & 1 \\
\hline 3 & Autografting & 1 & - & 2 & 3 \\
\hline & Total & 6 & 9 & 18 & 33 \\
\hline
\end{tabular}

Amputations of various limb segments were performed in $29(87.9 \%$ of all patients operated on), necrectomy in $1(3.1 \%)$, and autografting in $3(9.0 \%)$ patients. Six $(5.5 \%)$ patients underwent amputations of segments of both upper and lower extremities. Of 38 patients with hypothermia, surgeries were performed on $29(76.3 \%)$, of which $16(42.1 \%)$ had amputations of limb segments.

The treatment duration for all the ICU patients with cold injury was $4.2 \pm 2.1 \mathrm{bed} / \mathrm{days}$, and for the patients with combined hypothermia $-7.9 \pm 4.4 \mathrm{bed} /$ days. The total treatment duration of the patients in the hospital was $24.0 \pm 12.6$ bed/days, the patients with hypothermia $-26.8 \pm 18.2 \mathrm{bed} /$ days .

Over the study period, $3(2.7 \%)$ patients with cold injury died. Of the patients with hypothermia, one $(0.9 \%)$ died of cardiovascular collapse in the early post-thaw phase.

The current study covers only the treatment at the specialized ward and does not take into account the data on patients with cold injury who were treated in district hospitals; neither does it analyze the official mortality data from the Territorial Authority of the Federal State Statistics Service in the SR(Y). In fact, the situation with cold injury in the republic is far more acute. In our previous studies, we demonstrated that cold injury accounts for $11.4 \%$ of deaths in the structure of mortality from external causes in the republic, being one of the leading causes. ${ }^{(6,7)}$ According to the 2018 data, the mortality from cold injury was 13.3 per 100,000 population of the region. The relevance of the cold injury problem is also due to a high level of disability. The current study showed that $30.5 \%$ of the patients experienced amputation of extremities at various levels due to severe frostbite with tissue necrosis. Thus, the impact on public health from cold injury is one of the critical medical and social problems in the region.

At present, the republic's medical services face a number of objective difficulties in providing medical care to 
this category of patients. First, these are organizational-tactical issues due to the vast territory and inaccessibility of certain districts of the region. Among the constituent entities of the Russian Federation, Yakutia ranks first in area; while in terms of the population density, it is eighty-third out of 85 entities. Ninety percent of the region does not have year-round transport access. The cold season in the region lasts for 7 months, with the mean winter temperature of $-35^{\circ} \mathrm{C}$ to $-40^{\circ} \mathrm{C}$. Second, clinical issues related to cold injury also need to be tackled. There is no unified methodology for reliable diagnosis of the severity of tissue damage and the level of hypothermia, which makes timely and adequate treatment of patients impossible. In addition, today there are no domestic standards and clinical guidelines for the treatment of patients with hypothermia, including the use of active rewarming methods. All of these deficiencies need to be solved through a wider use of modern communications and the potential of telemedicine, as well as the development and adoption of national guidelines for the diagnosis and treatment of patients with cold injury, including the best international practices.

\section{Competing Interests}

The authors declare that they have no competing interests.

\section{References}

1. Diagnosis and Treatment of Frostbite (Clinical Guidelines, 2017). http://combustiolog.ru/wp-content/uploads/2013/07/ Diagnostika-i-lechenie-otmorozhenij-2017.pdf

2. State of Alaska: Cold Injuries Guidelines 2014. http:// mra.org/wp-content/uploads/2016/05/Alaska-DHSS-EMSCold-Injuries-Guidelines-June-2014.pdf

3. European Resuscitation Council Guidelines for Resuscitation 2015 Section 9. First aid. https://www.resuscitationjournal.com/ article/S0300-9572(15)00343-3/fulltext

4. Monika BM, Martin D, Balthasar E, et al. The Bernese Hypothermia Algorithm: a consensus paper on in-hospital decision-making and treatment of patients in hypothermic cardiac arrest at an alpine level 1 trauma centre. Injury. 2011;42(5):539-543. doi:10.1016/j.injury.2010.11.037

5. Order of the Ministry of Health of the Russian Federation No. 174 dated May 17, 1999: "On the measures on further improvements in tetanus prophylaxis."

6. Ivanova A., Potapov A., Alekseev R., Semenova S. Cold injury as a cause of disability and mortality of population in the region of the High North. NJDIS 2017;5(1): 66-70.

7. Ivanova AA, Potapov AF, Bosikov DV, Bulatov $\mathrm{AV}$, Makarova TS. External causes in the structure of premature mortality in the Republic of Sakha (Yakutia). International Journal of Biomedicine. 2019;9(1):75-79. 